Piotr Drożḋ̇ewicz Pallotyńska Szkoła Nowej Ewangelizacji w Lublinie

\title{
Misyjne przeobrażenie Kościoła i nawrócenie duszpasterstwa w świetle adhortacji Evangelii gaudium
}

\section{MISSIONARY TRANSFORMATION OF THE CHURCH AND THE PASTORAL CONVERSION ACCORDING TO THE ADHORTATION EVANGELII GAUDIUM}

Missionary transformation of the Church and the pastoral conversion is a basic postulate in the teaching of pope Francis. He sees in it one of the most urgent tasks, which the community of the Church has to face now. The transformation has to rely primarily on the total focusing on evangelization, what was the experience of the community of the early Christians. Everything in the Church, each of its space and structure, has to serve the fundamental vocation for preaching the Gospel. For this purpose it is necessary to revise the existing methods, forms and language of evangelization, and update them to modern socio-cultural conditions. The author of Evangelii gaudium points to the vision of the Church coming out to the man to find him in his living environment, to lead to the experience of a personal encounter with God and start participating in the Community. Not only ecclesiastical structures, but also the life of every baptized person should become of evangelistic orientation, manifesting itself in full of enthusiasm answering for personal call to evangelization.

Key words: new evangelization, pastoral conversion, pastoral conversion, Pope Francis, Evangelii gaudium. 


\section{Wprowadzenie}

Kościół zrodził się z misji Jezusa, którą pozostawił swoim uczniom odchodząc z tego świata ${ }^{1}$. Wzrost i rozwój wspólnoty jest skutkiem ochoczej odpowiedzi na ewangelizacyjny nakaz Mistrza z Nazaretu, której udzielili Apostołowie, a następnie kolejne pokolenia wierzących. Głoszenie Ewangelii jest zatem związane z Kościołem i stanowi o jego istocie ${ }^{2}$. Ewangelizacyjna misja wprowadza chrześcijan w serce Boga, którego najgłębszym pragnieniem jest doprowadzenie każdego człowieka do Zbawienia (por. 1 Kor 2, 4) ${ }^{3}$. Celem głoszenia Ewangelii jest spełnienie woli Bożej dotyczącej Zbawienia, nie jest ono więc jednym z zadań Kościoła, ale eliksirem jego życia i wyrazem jego istoty ${ }^{4}$. Lineamenta do Synodu Biskupów nt. „Nowa ewangelizacja dla przekazu wiary chrześcijańskiej" przypominają słowa Pawła VI, który podkreślił, iż ewangelizacja stanowi pierwszorzędne i naturalne posłannictwo Kościoła, które powinien uważać za łaskę i właściwe powołanie ${ }^{5}$. Autor Evangelii nuntiandi stwierdził jasno, że „Kościół jest dla ewangelizacji”".

Papież Franciszek zauważył, iż z biegiem czasu i rozwoju chrześcijaństwa, w wielu rejonach świata działalność Kościoła, w mniejszym lub większym stopniu, utraciła swe ewangelizacyjne ukierunkowanie, a jej miejsce zajęła troska o zachowanie i rozwój zdobytej przez Kościół pozycji w narodzie i kulturze, oraz utrzymanie w swych szeregach ludzi już ochrzczonych ${ }^{7}$. Stąd, by Kościół mógł w pełni realizować swe najgłębsze powołanie, niezbędne jest dziś misyjne przeobrażenie całej wspólnoty wierzących i nawrócenie duszpasterstwa ${ }^{8}$. Konieczność

1 Por. Synod Biskupów - XIII Zwyczajne Zgromadzenie Ogólne, Nowa ewangelizacja dla przekazu wiary chrześcijańskiej. Lineamenta (dalej: Lin), Watykan 2011, 2.

2 Por. Sobór Watykański II, Dekret o misyjnej działalności Kościoła Ad gentes divinitus (dalej: DM), [w:]Sobór WatykańskiII. Konstytucje. Dekrety. Deklaracje, Poznań 2002, 2.

Por. I. Dias, Ewangelizacja dzisiaj, [w:] G. Augustin (red.), Nowa ewangelizacja. Impulsy do ożywienia wiary, Ząbki 2012, s. 87.

Por. G. Augustin, Drogi skutecznej ewangelizacji, [w:] idem (red.), Nowa ewangelizacja. Impulsy do ożywienia wiary, Ząbki 2012, s. 139.

5 Por. Paweł VI, Adhortacja apostolska o ewangelizacji w świecie współczesnym Evangelii nuntiandi (dalej: EN), Wrocław 2001,14; Lin 2.

EN 14.

7 Por. Franciszek, Adhortacja apostolska o głoszeniu Ewangelii w dzisiejszym świecie Evangelii gaudium (dalej: EG), Kraków 2013, 27.

Por. EG 25. 
tę Franciszek wskazuje w swoich licznych wypowiedziach, a także poświęcił jej pierwszy rozdział adhortacji Evangelii gaudium. Można więc stwierdzić, iż urzędujący następca św. Piotra postrzega ją jako najważniejsze i najbardziej pilne zadanie Kościoła.

\section{Misyjne przeobrażenie Kościoła}

Postulat misyjnego ukierunkowania Kościoła nie jest nowy, gdyż sięga początków chrześcijaństwa i ówczesnego dynamizmu misyjnego, którym naznaczona była cała działalność wspólnoty Kościoła. Pierwsi chrześcijanie potrafili nieustannie poszukiwać nowych okoliczności do głoszenia Ewangelii, nie byli w stanie zatrzymać jej dla siebie i pod natchnieniem Ducha Świętego nieśli ją na krańce świata ${ }^{9}$. Franciszek wskazuje, iż także dziś całe Ciało Chrystusa wraz ze wszystkimi strukturami ma przyjąć misyjne ukierunkowanie ${ }^{10}$. Wszystkie jego działania muszą być podporządkowane zadaniu głoszenia Ewangelii współczesnemu człowiekowi, a więc wszystko, cokolwiek czyni, ma głosić Ewangelię i prowadzić człowieka do osobowego spotkania z Bogiem. Odmienione duszpasterstwo musi zakładać nową wizję Kościoła - wizję Kościoła ewangelizującego, który z ogromnym i pełnym zaangażowania zapałem wszystkie swoje siły włoży w próbę przyprowadzenia do Chrystusa tych, którzy utracili osobistą relację z Nim i odeszli ze wspólnoty ${ }^{11}$. George Augustin trafnie opisuje ewangelizacyjne ukierunkowanie Kościoła stwierdzając, iż nie wolno oddzielić działań duszpasterskich Kościoła od jego misji ${ }^{12}$. Jego zdaniem „misje nie stanowią jednego z wymiarów duszpasterstwa, lecz całe duszpasterstwo musi mieć charakter misyjny"13. Papież Franciszek podkreśla, że dla każdego dzieła kościelnego wzorcem jest działalność misyjna ${ }^{14}$. Dokument z Aparecidy, wydany jako pokłosie V Konferencji Ogólnej Episkopatu Ameryki Łacińskiej i Karaibów, podkreśla, że konieczne jest przejście „od duszpasterstwa zwykłego zachowywania stanu rzeczy

9 Por. Konferencja Episkopatów Ameryki Łacińskiej i Karaibów, Aparecida. V Ogólna Konferencja Episkopatów Ameryki Łacińskiej i Karaibów. Dokument końcowy. Jesteśmy uczniami i misjonarzami Jezusa Chrystusa, aby nasze narody miaty w Nim życie, Gubin 2014, 369.

10 Por. EG 27.

11 Por. S. Dyk, Nowa ewangelizacja - konkretne wezwanie, Gubin 2015, s. 141.

$12 \quad$ Por. G. Augustin, Drogi skutecznej ewangelizacji, s. 138;

$13 \quad$ Ibidem, s. 138.

14 Por. EG 15. 
Teologia papieża Franciszka do duszpasterstwa zdecydowanie misyjnego"15. Działalność Kościoła, która skupia się na utrzymywaniu i podtrzymywaniu tego, co udało się mu osiągnąć, w rzeczywistości sprawia zahamowanie jego rozwoju ${ }^{16}$.

Aby duszpasterstwo przybrało ewangelizacyjne ukierunkowanie niezbędna jest refleksja zarówno na poziomie Kościoła powszechnego, jak i partykularnego. Potrzebne jest dokonanie rozeznania duszpasterskiego, które pozwoli ocenić poziom życia chrześcijańskiego w poszczególnych Kościołach lokalnych ${ }^{17}$. Należy stanąć w prawdzie o tym, jak wielkie spustoszenie dokonały sekularyzacja, dechrystianizacja i konsumpcjonizm, tak bardzo uderzające w chrześcijańską tożsamość na progu nowego tysiąclecia. Nie wolno uciekać od konfrontacji z tą trudną sytuacją i uznania pewnych przestrzeni działalności Kościoła za nieaktualne i niedostosowane do współczesności ${ }^{18}$. Przyczyn obecnej sytuacji nie można dopatrywać się jedynie w złym świecie, ale z pokorą należy je dostrzec również we wnętrzu Ciała Chrystusa ${ }^{19}$. Właściwą postawą nie jest przyjmowanie postawy obronnej i udawanie, że nic się nie stało, lecz odważne poszukiwanie rozwiązania, które przyniesie poprawę sytuacji. Zebrane wnioski pozwolą na opracowanie konkretnej strategii ewangelizacji, której następnie trzeba będzie podporządkować całe działanie Kościoła.

Postulując nawrócenie duszpasterstwa i jego struktur, Franciszek nie rozpoczyna od spojrzenia na wszystkich wokół, ale na samego siebie. Pisze o nawróceniu papiestwa i zaznacza, iż Biskup Rzymu powinien być otwarty na sugestie odnoszące się do swej posługi, tak by mógł ją uczynić bardziej wierną zamysłowi Chrystusa i ewangelizacyjnej działalności Kościoła ${ }^{20}$. Jako głowa Kościoła musi on w sposób szczególny promować dzieło nowej ewangelizacji i troszczyć się o misyjne przeobrażenie całej wspólnoty.

15 Konferencja Episkopatów Ameryki Łacińskiej i Karaibów, Aparecida. VOgólna Konferencja Episkopatów Ameryki Łacińskiej i Karaibów. Dokument końcowy. Jesteśmy uczniami i misjonarzami Jezusa Chrystusa, aby nasze narody miaty w Nim $\dot{z} y c i e, 370$.

16 Por. D. Rey, Definicja nowej ewangelizacji, [w:] P. Sowa, K. Kaproń (red.), Kerygmatyczny impuls $w$ Kościele, Gubin 2012, s. 52.

17 Por. S. Dyk, Nowa ewangelizacja-konkretne wezwanie, s. 141.

18 Por. L. M. Pignatiello, Comunicare la fede. Saggi di teologia pastorale, Torino 1996, s. 40

19 Por. EG 63.

20 Por. ibidem, 32. 


\section{Nawrócenie duszpasterskie Kościoła lokalnego}

Do misyjnego nawrócenia jest zaproszony w sposób szczególny każdy Kościół lokalny, który stanowi cząstkę Kościoła powszechne$\mathrm{go}^{21}$. W danym miejscu na ziemi jest on wyrazem powszechności Ciała Chrystusowego, które jest w nim prawdziwie obecne wraz ze swymi wszystkimi przymiotami. Wspólnota Kościoła lokalnego jest wpisana w określone terytorium i dysponuje „wszystkimi środkami zbawienia przekazanymi przez Chrystusa, lecz z lokalnym obliczem"22. Nawrócenie duszpasterskie w pierwszej kolejności ma stać się udziałem pasterza diecezji i całego prezbiterium. Zadaniem biskupa jest sprzyjanie komunii misyjnej w swojej diecezji i dążenie do ewangelizacyjnego ideału pierwszej wspólnoty chrześcijańskiej ${ }^{23}$. Ordynariusz i jego współpracownicy powinni swe siły pożytkować nie na organizowanie instytucjonalnego wymiaru wspólnoty, ale na realizację misyjnego pragnienia o dotarciu z Ewangelią do wszystkich swych podopiecznych ${ }^{24}$. Nawrócenie Kościoła lokalnego, podobnie jak w przypadku Kościoła powszechnego, ma uwrażliwić wspólnotę na wagę misji ewangelizacyjnej i pobudzić do aktywnego działania na rzecz uczynienia jej priorytetem we wszystkich przejawach działalności wspólnoty lokalnej. Wszystkie wydziały Kurii i struktury Kościoła partykularnego powinny zostać nastawione na realizację wezwania do nowej ewangelizacji. Biskupi zgromadzeni na V Ogólnej Konferencji Episkopatów Ameryki Łacińskiej i Karaibów w dokumencie końcowym stwierdzają, iż cały plan pastoralny każdej diecezji - „konkretne elementy programu, cele i metody pracy, zasady formacji i doskonalenia duszpasterzy i ich współpracowników"25 - powinien być kształtowany tak, by jak najbardziej skutecznie głosić Ewangelię współczesnemu człowiekowi ${ }^{26}$. Duszpasterskie nawrócenie lokalnej wspólnoty wierzących owocować będzie pobudzeniem całej społeczności do aktywnego zaangażowania w głoszenie Ewangelii.

\footnotetext{
$21 \quad$ Por. ibidem, 30.

22 Ibidem, 30.

23 Por. EG 31.

24 Por. ibidem, 31.

25 Konferencja Episkopatów Ameryki Łacińskiej i Karaibów, Aparecida. V Ogólna Konferencja Episkopatów Ameryki Łacińskiej i Karaibów. Dokument końcowy. Jesteśmy uczniami i misjonarzami Jezusa Chrystusa, aby nasze narody miaty w Nim $\dot{z} y c i e, 371$.

Por. ibidem, 371 .
} 


\section{Misyjne ukierunkowanie parafii i jej pastoralne nawrócenie}

Parafia jest podstawowym środowiskiem potrzebującym misyjnego przeobrażenia i pastoralnego nawrócenia. Dzieło nowej ewangelizacji wymaga nowej parafii, która wszystkie swoje siły zaangażuje w głoszenie Dobrej Nowiny. Evangelii gaudium podkreśla szczególną rolę tej podstawowej komórki w ewangelizacyjnej działalności Kościoła ${ }^{27}$. Jest ona znakiem i formą obecności Kościoła powszechnego na danym terytorium, a zatem wszystko, co w kwestii nowej ewangelizacji można powiedzieć o całej wspólnocie Kościoła, należy odnieść w pierwszej kolejności do parafii, w której to dzieło realizuje się w sposób konkretny. Papież Franciszek zauważa również bogactwo metod i form ewangelizacji, które mogą być realizowane we wspólnocie parafialnej $\mathrm{z}$ racji na jej wielką elastyczność ${ }^{28}$. Parafia powinna być miejscem doświadczenia wiary i jej wzrostu zwłaszcza w obliczu kryzysu rodziny, która w wielu regionach świata przestała być pierwszą wspólnotą żywej wiary, miłości i jedności ${ }^{29}$.

Jan Wal wymienia trzy modele wspólnot parafialnych: usługowe, które świadczą usługi religijne; familiarne, które budują się do wewnątrz i stanowią swoiste getto; i misyjne, które budując się do wewnątrz pozostają otwarte na zewnątrz ${ }^{30}$. W świetle adhortacji Evangelii gaudium najlepszym modelem jest oczywiście ostatni. Papież Franciszek stwierdza jasno, iż wspólnota parafialna musi całkowicie ukierunkować się na misję ${ }^{31}$. Nie może ona skupić się jedynie na tych, którzy pojawiają się co tydzień na Eucharystii i mniej lub bardziej angażują się w jej życie. Nowa parafia, jak cały Kościół, ma wychodzić poza samą siebie i poszukiwać tych, których nie ma w kościele ${ }^{32}$. Ma również za zadanie skierować ożywiającą moc Dobrej Nowiny na tych, którzy mimo podejmowania praktyk religijnych, nie posiadają żywej wiary i osobowej relacji z Bogiem. Skupienie oddziaływania jedynie na tych,

$27 \quad$ Por. EG 28.

Por. ibidem, 28.

Por. Konferencja Episkopatów Ameryki Łacińskiej i Karaibów, Aparecida. V Ogólna Konferencja Episkopatów Ameryki Łacińskiej i Karaibów. Dokument końcowy. Jesteśmy uczniami i misjonarzami Jezusa Chrystusa, aby nasze narody miaty w Nim życie, 304.

Por. J. Wal, Diakonia wspólnoty a przekaz wiary chrześcijańskiej, [w:] G. W. Dryl (red.), Nowy człowiek w dziele nowej ewangelizacji, Kraków 2013, s. 185.

Por. EG 28.

Por. G. Ryś, Nowa ewangelizacja dla przekazu wiary, [w:] G. W. Dryl (red.), Nowy człowiek $w$ dziele nowej ewangelizacji, s. 28. 
którzy doświadczyli już spotkania z Bogiem i są we wspólnocie, jest jedną z najczęstszych pokus parafialnego duszpasterstwa. Takie duszpasterstwo staje się ekskluzywne i prowadzi do powstania chrześcijańskiego getta, skupionego tylko na sobie. Misją nowej parafii nie jest jedynie konserwowanie tego, co już udało jej się osiągnąć, ale odważne wychodzenie naprzeciw ludziom, którzy odłączyli się od Boga i Kościoła. Wspólnota parafialna nie będzie doświadczała wzrostu, dopóki pierwszego miejsca w jej działalności nie zajmie ewangelizacja osób, które nie wierzą i nie podejmują praktyk religijnych lub uczęszczają do Kościoła pomimo braku osobowej relacji z Bogiem. Jeśli nowa ewangelizacja nie stanie się pastoralnym priorytetem parafii i wspólnot ją tworzących, zamkną się one w sobie, popadną w samozachwyt i będą dążyły jedynie do usatysfakcjonowania swoich członków. Cała wspólnota parafialna, zarówno jej duszpasterze, jak i wszyscy parafianie, powinna stale troszczyć się o ewangelizacyjną twórczość i poszukiwać nowych sposobów dotarcia do swoich niezewangelizowanych członków. Musi jej towarzyszyć nieustanna gotowość do reformowania się i przystosowywania do aktualnej sytuacji społeczno-kulturowej ${ }^{33}$. Parafia nie może poprzestać na wypracowanych już metodach i formach ewangelizacji, gdyż patrząc na liczbę swoich członków oddalonych od Boga i wspólnoty, z pokorą musi uznać je za niewystarczające i nieaktualne. Dzisiejszy świat przynosi człowiekowi wielką ilość atrakcji, które odciągają go od zaangażowania w życie parafialne i wspólnotowe. Jeśli parafia chce przyprowadzić go do Kościoła i żywej relacji z Bogiem, jej metody i formy ewangelizacyjnego oddziaływania muszą stać się dla niego nie tylko aktualne, ale również atrakcyjne.

Papież Franciszek zadanie parafii określa jako towarzyszenie swoim podopiecznym w taki sposób, by ewangelizatorzy wychodzący ku zagubionym owcom mieli na sobie ich zapach ${ }^{34}$. Duszpasterze i odpowiedzialni za ewangelizację we wspólnocie muszą znać okoliczności życia i problemy tych, wśród których żyją. Ich nieznajomość stanowi konkretny hamulec dzieła ewangelizacji i wzrostu wspólnoty. Wspólnota ma być blisko ludzi, gdyż brak tej bliskości uniemożliwi skuteczne głoszenie Ewangelii ${ }^{35}$. W wielu regionach świata wspólnoty chrześcijańskie na własne życzenie wyobcowały się ze swoich środowisk i nie znają potrzeb lokalnych społeczności, przez co nie są w stanie odpowiednio zinkulturować Dobrej Nowiny i dotrzeć z nią do tych, których nie ma w kościele. Brak wychodzenia poza bramy kościoła

$33 \quad$ Por. EG 28.

34 Por. EG 24.

35 Por. ibidem, 24. 
Teologia papieża Franciszka

na spotkanie z człowiekiem, który do niego nie przyjdzie, z pewnością jest łatwiejszy od wystawienia się na ryzyko popełnienia błędu czy odniesienia porażki, ale stanowi on rażące zaniedbanie podstawowego powołania wspólnoty, którym jest prowadzenie do Chrystusa. Wyjście na spotkanie z człowiekiem i poznanie okoliczności jego życia umożliwia wspólnocie sformułowanie odpowiedniej wizji ewangelizacyjnej oraz zaplanowanie działań, które pozwolą na skuteczne głoszenie Dobrej Nowiny. Wspólnoty chrześcijańskie powinny poznać oczekiwania otoczenia i wyjść im naprzeciw tak, by jak najwięcej ludzi pozyskać dla Chrystusa.

W ewangelizacyjnym przeobrażeniu parafii i wspólnot niezwykle istotne jest zaangażowanie wiernych w realizację wezwania do nowej ewangelizacji. Powinni oni pełnić zarówno funkcje przywódcze, jak i podejmować działalność w ramach poszczególnych posług wspólnoty ${ }^{36}$. Wielkim błędem jest skupienie całej odpowiedzialności w rękach duszpasterzy. Powinni oni dzielić się odpowiedzialnością i władzą ze świeckimi tak, by w pełni wykorzystać złożone w nich przez Boga dary i charyzmaty. Parafie i wspólnoty są szczególną przestrzenią Kościoła, która powinna rozbudzać ewangelizacyjną odpowiedzialność laikatu, wypływającą z sakramentów chrztu i bierzmowania ${ }^{37}$. Niestety w wielu wspólnotach świeccy trzymani są na dystans od ewangelizacyjnego zaangażowania, gdyż uważa się ich za zdolnych nie do posługi, ale do przyglądania się jej i korzystania z jej owoców ${ }^{38}$. Duszpasterze i liderzy nie mogą wykorzystywać swej pozycji do realizacji osobistych planów i celów, ale powinni pełnić swą misję tak, by umożliwić wszystkim członkom swych wspólnot rozwijanie posiadanego przez nich ewangelizacyjnego potencjału ${ }^{39}$. Działanie liderów w pojedynkę ogranicza skuteczność ewangelizacyjnych przedsięwzięć do ich własnych pomysłów i możliwości. Zadaniem odpowiedzialnych jest zaangażowanie wszystkich członków wspólnoty w jej ewangelizacyjne posłannictwo, stosownie do ich możliwości, darów i umiejętności ${ }^{40}$. Oczywiście

36

Por. P.-A. Giffard, Wzrastanie Kościoła. Narzędzia i sposoby ożywienia wiary $w$ parafii, Gubin 2013, s 49.

37

38

Por. EG 102.

Por. Rada ds. Apostolstowa Świeckich przy Episkopacie USA, Co-workers in the vineyard of the Lord: A resource for guiding the development of lay ecclesial ministry, Washigton DC 2005, s. 11.

Por. P.-A. Giffard, Wzrastanie Kościoła. Narzędzia i sposoby ożywienia wiary $w$ parafii, s. 49 .

Por. M. White, T. Corcoran, Odbudowana. Czylijak przebudzić wiernych, dotrzeć do zagubionych i nadać Kościołowi znaczenie, Gubin 2013, s. 231-232. 
początkowo powinny to być mało wymagające i niezbyt angażujące czasowo zadania, które umożliwią im sprawdzenie się w danej posłudze przy jednoczesnym poczuciu otrzymania odpowiedzialności i związanej z tym satysfakcji. Stopniowo można powierzać wiernym bardziej odpowiedzialne zadania, które zwiększą ich zaangażowanie i związek ze wspólnotą. Wiadomo, że nie każdy będzie głosił Ewangelię na ulicy czy prowadził modlitwę na spotkaniu wspólnoty, ale istnieje wiele różnych posług, jak choćby parzenie kawy czy troska o czystość podczas spotkań ewangelizacyjnych. Ważne jest uświadamianie posługujących, iż nie ma posług nieważnych, gdyż każda posługa, bez względu na stopień jej trudności i związanej z nią odpowiedzialności, włączona jest w całość ewangelizacyjnej działalności wspólnoty i umożliwia owocne jej prowadzenie.

Misyjne zaangażowanie wszystkich wiernych sprowadza na odpowiedzialnych za wspólnoty obowiązek dostarczenia im odpowiedniej formacji. Parafie i wspólnoty powinny formować i kształtować swoich podopiecznych tak, by nigdy nie byli jedynie uczniami, lecz zawsze uczniami-misjonarzami ${ }^{41}$. Liderzy mają zachęcać swoich członków do tego, by z oddaniem angażowali się w ewangelizacyjną działalność swojej wspólnoty. Ich zadaniem jest rozbudzenie w nich odpowiedzialności za dzieło nowej ewangelizacji Kościoła, która sprawi, że nie będą mogli zatrzymać dla siebie doświadczenia spotkania z żywym Bogiem, ale zapragną ofiarnie głosić Go tym, wśród których żyją.

Wspólnota ewangelizacyjna nie jest obojętna na owoce swojej misji. Ma świadomość, że zależą one całkowicie od daru Bożej łaski, ale zwraca na nie uwagę, gdyż wie, iż Bóg oczekuje jej apostolskiej płodności ${ }^{42}$. Widząc niepowodzenia w dziele ewangelizacji, wspólnota nie załamuje się i nie lamentuje. Z odwagą i twórczością wyszukuje sposobów, by Ewangelia wydała owoce w konkretnych okolicznościach życia, nawet jeśli początkowo wydają się być niedojrzałe lub niedoskonałe. Bóg nie tylko pragnie owoców ewangelizacyjnej działalności wspólnoty, lecz także je obiecał i sam się o nie troszczy (por. J 15, 16; Mt 21, 43; Mk 16, 17-18; Dz 2, 47). Gdy działalność ewangelizacyjna parafii i wspólnoty nie przynosi rezultatów, należy zatrzymać się i zadać pytanie, czy są one wierne Bogu wzywającemu je do głoszenia Ewangelii ${ }^{43}$. Wspólnota ma się wówczas zastanowić, co robi niewłaściwie, co należy zachować,

$41 \quad$ Por. EG 120.

42 Por. ibidem, 24.

43 Por. M. White, T. Corcoran, Odbudowana. Czylijak przebudzić wiernych, dotrzeć do zagubionych i nadać Kościołowi znaczenie, s. 47-48. 
a co odrzucić. Wszystko po to, by jak najowocniej realizować powołanie, które stanowi o jej tożsamości i istocie.

\section{Pastoralne nawrócenie wszystkich członków Kościoła}

Nawrócenie duszpasterstwa w kluczu ewangelizacyjnym musi stać się udziałem poszczególnych członków Kościoła. W pierwszej kolejności powinno ono stać się udziałem tych, którzy przewodzą ewangelizacyjnej misji Kościoła, a więc biskupów, kapłanów i liderów wspólnot, gdyż „nawrócenie grzeszników jest wynikiem nawrócenia pasterzy” ${ }^{44}$. Jeśli życie każdego z chrześcijan nabierze ewangelizacyjnego ukierunkowania, jednocześnie nabierze go cała wspólnota Kościoła. W życiu chrześcijan ma się ono przejawiać pełną zapału i gotowości do poświęceń realizacją osobistego powołania do głoszenia Ewangelii. Wszyscy członkowie Ludu Bożego powinni odkryć, iż ich życie w Bogu wzrasta i dojrzewa, gdy z radością przekazują je innym ${ }^{45}$. Kiedy z wygody lub lęku nie dzielą się ze światem otrzymaną łaską Zbawienia, ich życie duchowe ulega osłabieniu i deformacji. Każdy ochrzczony powinien zrozumieć, iż wzywając go do misyjnego zaangażowania, Kościół ukazuje mu drogę osobistego rozwoju i satysfakcjonującej realizacji chrześcijańskiego powołania.

Życie chrześcijan musi być głęboko przeniknięte słowami św. Pawła: „biada mi, gdybym nie głosił Ewangelii” (1 Kor 9, 16) ${ }^{46}$. Powinni oni odkryć, że wezwanie do głoszenia nie jest dla nich kwestią wyboru, ale nakazem pozostawionym przez ich Pana ${ }^{47}$. Zwracał na to uwage już Paweł VI, który pisał, iż ludzie, którym zaniechamy głosić Ewangelię, dzięki Miłosierdziu Boga będą mogli doświadczyć Zbawienia na innych drogach, ale chrześcijan powinno nurtować pytanie o to, czy oni dostąpią Zbawienia, jeśli z powodu lęku, wstydu czy lenistwa zrezygnują z dzieła ewangelizacji ${ }^{48}$. Niektórzy teolodzy uznają, iż głoszenie Ewangelii jest nie tylko podstawowym zadaniem ochrzczonych, ale także warunkiem ich Zbawienia ${ }^{49}$. Chrześcijanin, który nie ewangelizuje, odrzuca misyjny nakaz swego Zbawiciela i Pana, sprzeciwiając się swemu podstawowemu powołaniu. Jose Prado Flores, świecki

$44 \quad$ D. Rey, Definicja nowej ewangelizacji, s. 58.

45 Por. EG 10.

46 Por. ibidem, 9.

47 Por. I. Dias, Ewangelizacja dzisiaj, s. 87.

$48 \quad$ Por. EN 74.

49 Por. Cz. Parzyszek, Znaczenie nowej ewangelizacji dla odnowy wspótczesnego świata, Ząbki 2012, s. 85. 
ewangelizator i założyciel działającej w kilkudziesięciu krajach świata Szkoły Ewangelizacji Świętego Andrzeja, odważył się wręcz stwierdzić, iż jeśli osoba ochrzczona nie głosi Ewangelii, nie może nazywać się ani nie jest uczniem Jezusa i chrześcijaninem ${ }^{50}$. Nie można być chrześcijaninem i uczniem, jeśli nie odpowiada się na Chrystusowy nakaz ewangelizacji, gdyż należy on do istoty tożsamości chrześcijanina i ucznia. Nakaz ewangelizacji łączy się z największym z przykazań - przykazaniem miłości Boga i bliźniego. Najlepszą bowiem drogą miłowania Boga i bliźniego jest głoszenie bezwarunkowej miłości Ojca i dzieła Zbawienia, którego dokonał Jego Syn ${ }^{51}$. Ewangelizacja jest wyrazem miłości względem Boga, gdyż przez nią prowadzi On ludzi do Zbawienia, a to jest Jego największym pragnieniem. Jest ona również drogą miłowania bliźniego, ponieważ doprowadzenie go do żywego spotkania z Bogiem i doświadczenia zbawienia stanowi największe dobro, jakie można komukolwiek ofiarować ${ }^{52}$.

Ewangelizacyjne przeobrażenie ma stać się udziałem każdego z ochrzczonych. Papież jasno stwierdza, że powinno ono się ujawniać przede wszystkim w uznaniu ewangelizacji za istotę swojej tożsamości $^{53}$. Nowe zaangażowanie chrześcijan może się w nich zrodzić jedynie wtedy, gdy w pełni utożsamią się z pełnioną przez siebie posługą, tak iż będą mogli powiedzieć ,ja jestem misją na tym świecie”"54. Ewangelizacyjna działalność nie jest dla członków Ludu Bożego częścią ich życia lub jakimś dodatkiem, który może być dowolnie przyjęty lub odrzucony. Franciszek podkreśla, że jest ona czymś, z czego nie można zrezygnować, jeśli nie chce się siebie zniszczyćc ${ }^{55}$. Zachęca on wszystkich wiernych: „trzeba przyjąć samych siebie jako naznaczonych ogniem przez tę misję" "56. Nowi ewangelizatorzy muszą zrezygnować z wygodnego poczucia bezpieczeństwa i podjąć z pasją zadanie głoszenia Ewangelii światu ${ }^{57}$. Misja ta nie może być pełniona z grobową miną, smutkiem, zniechęceniem czy lękiem, lecz potrzebuje świadków

50 Por. J. P. Flores, Nowi ewangelizatorzy dla nowej ewangelizacji, Poznań 2013, S. 84-85.

51 Ibidem, s. 83.

52 Por. EG 156.

53 Por. EG 78.

$54 \quad$ Ibidem 273.

55 Por. ibidem, 273.

$56 \quad$ Ibidem, 273.

57 Por. ibidem, 10. 
Teologia papieża Franciszka

pełnych zapału i radości, gdyż tylko oni mogą skutecznie przekazywać życie zaczerpnięte od Boga ${ }^{58}$.

Nowemu ewangelizatorowi musi towarzyszyć świadomość, że trudności i mroki współczesnego świata są w świetle wiary szczególną przestrzenią, w którą może wejść światło Ewangelii, przynosząc jej przemianę i uzdrowienie ${ }^{59}$. Dzieje się tak, gdyż jak powiedział św. Paweł „gdzie wzmógł się grzech, tam jeszcze obficiej rozlała się łaska” (Rz 5, 2). Jednym z podstawowych błędów, który całkowicie hamuje ewangelizacyjny zapał chrześcijan, jest poddanie się bez walki i ogłoszenie kapitulacji ${ }^{60}$. Nigdy nie może wkraść się w serce głoszącego poczucie przegranej, które przemieni go w niezadowolonego i rozczarowanego pesymistę. Autor Evangelii gaudium wskazuje, iż „nikt nie może podjąć walki o zbawienie braci, jeśli nie wierzy w zwycięstwo" "21. Zaczynając dzieło ewangelizacyjne bez nadziei i ufności, traci się szansę na powodzenie i zakopuje swoje talenty. Poczucie przegranej Franciszek widzi jako działanie złego ducha, który próbuje zniechęcić i wprowadzić w lęk.

Ewangelizacyjne ukierunkowanie ochrzczonych nie pozwoli im zwlekać z rozpoczęciem misji do czasu, gdy będą do niej całkowicie przygotowani, a ich życie będzie odznaczało się całkowitą świętością ${ }^{62}$. Ani jedno, ani drugie nie jest zresztą możliwe. $Z$ jednej strony ewangelizator doświadcza, iż pełniona posługa zawsze go przerasta, a jej skuteczność zależy od prowadzącego go w niej Ducha Świętego ${ }^{63}$. Z drugiej zaś jego świętość nie polega nigdy na bezgrzeszności i gdyby ktoś chciał odkładać rozpoczęcie ewangelizacji do czasu usunięcia wszystkich niedoskonałości, nigdy by jej nie rozpoczął. Franciszek z całą mocą wskazuje, iż niedoskonałość moralna lub brak należytego przygotowania do ewangelizacji nie mogą sprawić rezygnacji z misji ${ }^{64}$. Niezależnie od aktualnej kondycji moralnej i doświadczenia, każdy chrześcijanin jest wezwany do wyraźnego głoszenia miłości Boga, który zbawia i obdarza łaską właśnie niedoskonałych i słabych. Niedoskonałość nie może być nigdy wymówką do zaniechania głoszenia.

58

Por. ibidem, 10.

Por. ibidem, 84.

Por. N. Medina, Dwanaście błędów, których nie możemy popetnić, [w:] P. Sowa, K. Kaproń (red.), Kerygmatyczny impuls w Kościele, Gubin 2012, s. 76.

EG 85.

Por. ibidem, 121.

Por. ibidem, 128.

Por. ibidem, 121. 
Wręcz przeciwnie, podjęcie dzieła nowej ewangelizacji jest bodźcem, który nie pozwoli godzić się z przeciętnością i da pragnienie stałego wzrostu $^{65}$. Nauczanie to stanowi pewne novum względem jego poprzedników na Stolicy Piotrowej, którzy jako warunek podjęcia dzieła ewangelizacji wskazywali świętość życia i jego zgodność z Ewangelią. Jedynym warunkiem, o jakim pisze autor Evangelii gaudium, jest osobiste spotkanie z miłującym człowieka Bogiem, które daje ochrzczonemu nie tylko możliwość ewangelizowania, ale sprawia, że nie jest on w stanie tego nie robićc6 ${ }^{66}$. Nawet doświadczając swojej własnej słabości i grzeszności, ewangelizator powinien odważnie kroczyć naprzód i nie brać pod uwagę myśli o poddaniu się. Kościół i jego ludzie nie mogą zatrzymać dla siebie Ewangelii, która przynosi nowe, obfite życie i pozwala doświadczyć zbawienia ${ }^{67}$.

\section{Ewangelizacja jako istotowe zadanie Kościoła}

Kwestia ewangelizacyjnego przeobrażenia i nawrócenia Kościoła dotyczy jego natury i istoty. Postulaty te nie są spowodowane jedynie względami funkcjonalnymi, zmierzającymi do poprawy działań ewangelizacyjnych i strategii głoszenia ${ }^{68}$. W swym najgłębszym znaczeniu są one pytaniem o to, czy Kościół nie zagubił swej istoty i podstawowego posłannictwa. Ewangelizacja jest powodem, dla którego Bóg powołał do istnienia Kościół, jeśli więc nie wypełnia on racji swego istnienia, zachwiany jest jego fundament i sens trwania ${ }^{69}$. W nawróceniu duszpasterskim chodzi więc o to, by Kościół nieustannie przyglądał się samemu sobie, odradzał się przez przyjęcie łaski oraz na nowo rozpoznawał znaczenie i charakter swej zbawczej misji wśród narodów. Odkrywając na nowo istotę i podstawowe posłannictwo, Kościół powinien porównać się z idealnym obrazem, jaki Jezus widział, jakiego zapragnął i jaki umiłował jako swą Oblubienicę, za którą oddał życie (por. Ef 5,27$)^{70}$. To porównanie ideału z rzeczywistym obliczem wspólnoty Kościoła powinno zrodzić w nim „ofiarne i niemal niecierpliwe pragnienie odnowy, to znaczy poprawy błędów" ${ }^{71}$, jakie w sobie dostrzega.

\footnotetext{
65 Por. ibidem, 121.

66 Por. EG 120-121.

67 Por. Lin 25.

68 Por. Lin 2.

$69 \quad$ Por. D. Rey, Definicja nowej ewangelizacji, s. 37.

70 Por. EG 26.

71 EG 26.
} 
Teologia papieża Franciszka

W soborowym dekrecie o ekumenizmie Unitatis redintegratio czytamy, że nawrócenie wspólnoty Kościoła jest otwarciem się na nieustanną reformę samej siebie, a „wszelka odnowa Kościoła w istocie polega na wzrastaniu w wierności jego powołaniu"72. Nawrócenie duszpasterskie i ewangelizacyjne Kościoła pozwoli mu powrócić do swego pierwotnego powołania, które stanowi o jej naturze ${ }^{73}$. Będzie to skutkowało rzeczywistym uznaniem nowej ewangelizacji za priorytetowe zadanie wspólnoty wierzących, któremu odda się ona w całości.

\section{Postawienie Boga w centrum życia i działalności Kościoła}

Istotą ewangelizacyjnego i duszpasterskiego nawrócenia jest postawienie Boga w centrum całej działalności Kościoła. Wydaje się to oczywiste, ale niejednokrotnie rzeczywistość pokazuje, że jakkolwiek w Kościele wiele mówi się o Bogu, to często dla wielu Jego dzieci pozostaje On jedynie ideą, bezosobowym zbiorem prawd wiary i przykazań, które nie mają rzeczywistego wpływu na ich życie ${ }^{74}$. W tej przestrzeni pierwszym problemem, którym powinien zająć się Kościół nie jest obecny w świecie zewnętrznym sekularyzm i ateizm, ale brak osobowej relacji z Bogiem i obojętność na Niego, które dotykają wnętrze wspólnoty. Kryzys działalności ewangelizacyjnej jest skutkiem kryzysu wiary, braku doświadczenia bezwarunkowej miłości Ojca i żywej relacji z Chrystusem. Papież Franciszek wyraźnie stwierdził, iż „każdy chrześcijanin jest misjonarzem w takiej mierze, w jakiej spotkał się z miłością Boga w Chrystusie" 75 . Dotyczy to zarówno całego duszpasterstwa i jego struktur, jak również wszystkich członków Ludu Bożego. Jeżeli duszpasterstwo i jego struktury nie są ukierunkowane na pełne dynamizmu i poświęcenia przepowiadanie Ewangelii, jest to znakiem tego, że ludzie za nie odpowiadający nie są rozpaleni miłością Chrystusa, która stanowi pierwszą motywację do podjęcia dzieła nowej ewangelizacji ${ }^{76}$. Bowiem „cóż to za miłość, która nie odczuwa potrzeby mówienia o ukochanej istocie, ukazywania jej, starania się, by inni ją poznali"77? Aby więc doświadczyć ewangelizacyjnego nawrócenia,

72 Sobór Watykański II, Dekret o ekumenizmie Unitatis redintegratio, [w:] Sobór Watykański II. Konstytucje. Dekrety. Deklaracje, Poznań 2002, 6.

73 G. Augustin, Drogi skutecznej ewangelizacji, s. 145.

74 Por. ibidem, s. 141.

75 EG 120 .

$76 \quad$ Por. ibidem, 264; Cz. Parzyszek, Znaczenie nowej ewangelizacji dla odnowy wspótczesnego świata, s. 85 . 
Kościół wraz ze swymi dziećmi musi zacząć na nowo wsłuchiwać się w głoszoną przez siebie Dobrą Nowinę o Zbawieniu. Powinien on mieć świadomość, że jest pierwszym adresatem nowej ewangelizacji. Autor Evangelii gaudium podkreśla, iż w życiu ewangelizatora niezbędne jest stałe odnawianie żywej relacji z Chrystusem i doświadczenia Zbawienia ${ }^{78}$. Nawiązując do słów Pawła VI, Lineamenta do Synodu poświęconego nowej ewangelizacji stwierdza, że „Kościół zaczyna od ewangelizowania samego siebie"79. Papież Franciszek wskazuje, że nieustannie muszą we wspólnocie Kościoła rozbrzmiewać treści pierwszego głoszenia, a więc prawdy o Bożej miłości objawionej w Jezusie Chrystusie, która przemienia życie ${ }^{80}$. Postuluje on również utworzenie dla osób zaangażowanych w ewangelizację odpowiednich przestrzeni, które będą służyły odnowie ich wiary, dzieleniu się przez nich swymi pytaniami i problemami oraz dostarczeniu motywacji do nieustannego podejmowania ewangelizacyjnej posługi wobec świata ${ }^{81}$. Jeśli w duszpasterstwie i jego strukturach Bóg będzie rzeczywiście na pierwszym miejscu, a relacja z Nim będzie punktem odniesienia dla całej kościelnej działalności, postulowane nawrócenie stanie się rzeczywistością, a wspólnota będzie pełna ewangelizacyjnego dynamizmu.

\section{Kościół wychodzący na poszukiwanie człowieka}

Papież Franciszek zauważa, że w Biblii, zarówno w Starym, jak i w Nowym Testamencie, niemal na każdym kroku można dostrzec dynamizm wyjścia, do którego Bóg wzywa wierzących ${ }^{82}$. W Chrystusowych nakazach ewangelizacji, odnotowanych przez Ewangelistów, wskazanie „idźcie” poprzedza drugie z poleceń - „ewangelizujcie”. Oznacza to, iż uczniowie nie mają głosić Ewangelii pozostając tam, gdzie przebywają. Nie mogą czekać na to, że nieznający Chrystusa sami odnajdą ich i poproszą o ewangelizację. Uczniowie mają najpierw iść, wychodzić poza bezpieczne dla nich miejsca, poszukiwać tych, którzy nie spotkali żywego Boga objawionego w Jezusie, a dopiero wówczas, gdy znajdą ich w okolicznościach i warunkach ich życia, mają im głosić Słowo.

Podstawowi adresaci nowej ewangelizacji, a więc chrześcijanie, którzy odeszli od Boga i wspólnoty Kościoła porzucając praktyki

\footnotetext{
78 Por. EG 266.

$79 \quad$ Lin 2; por. EN 15.

80 Por. EG 11.

81 Por. ibidem, 77.

82 Por. EG 20.
} 
Teologia papieża Franciszka chrześcijańskie lub podejmują je w oderwaniu od żywej relacji z Nim, pozostają poza obrębem oddziaływania zwykłego duszpasterstwa, zorganizowanego najczęściej na poziomie parafii. Mimo formalnego bycia wewnątrz Kościoła wskutek otrzymanego chrztu św., w rzeczywistości są oni na zewnątrz wspólnoty ${ }^{83}$. Kurt Koch zauważa, że minęły już czasy uspołecznienia chrześcijaństwa, które sprawiało, że człowiek stawał się chrześcijaninem i wrastał we wspólnotę Kościoła ze względu na urodzenie w społeczności chrześcijańskiej ${ }^{84}$. Do ludzi pozostających na zewnątrz wspólnoty nie można dotrzeć za pomocą metod i struktur, które znajdują się wewnątrz Kościoła. Nie można również oczekiwać, choć nierzadko tak się zdarza, iż to oni podejmą działanie jako pierwsi i zaczną szukać ewangelizującej wspólnoty. Należy ich szukać w ich środowisku życia, a więc na zewnątrz Kościoła. Ludzi, którzy odeszli od wiary i Boga, trzeba szukać tam, gdzie się znajdują. To poszukiwanie ma się dokonywać nie przez działania akcyjne, lecz konsekwentne i stałe. Duszpasterstwo ewangelizacyjne nie może oczekiwać biernie na ludzi pozostających poza obrębem Kościoła, lecz ma aktywnie poszukiwać zagubionych owiec ${ }^{85}$. Dokument z Aparecidy podkreśla, że „nie możemy dłużej pozostawać w spokoju, w biernym oczekiwaniu, w naszych kościołach" ${ }^{86}$. Kościół nie może trwać w bezruchu, który stanowi lęk przed nowym porządkiem duszpasterskim.

Franciszek pisze, że wyjście Kościoła poza siebie oznacza rezygnację z wygodnego kryterium duszpasterskiego, które stwierdza „zawsze tak się robiło” lub „nigdy się tak nie robiło" 87 . To wyjście wymaga odwagi, by swoje kroki skierować na peryferia świata, które potrzebują światła Dobrej Nowiny ${ }^{88}$. Wszyscy uczniowie są zaproszeni do ewangelizacyjnego dynamizmu wyjścia - poza siebie, poza własną wygodę i bezpieczeństwo, poza swoje przyzwyczajenia i schematy myślowe. Kościól, jak Jezus i Jego pierwsi uczniowie, ma dziś wychodzić poza siebie, by głosić Ewangelię człowiekowi wszędzie, gdzie się znajduje, korzystając z każdej możliwej okazji. Evangelii gaudium wskazuje, iż ma on być

83 Por. S. Dyk, Nowa ewangelizacja-konkretne wezwanie, s. 65.

Por. K. Koch, Misja czy dymisja Kościoła, [w:] G. Augustin (red.), Nowa ewangelizacja. Impulsy do ożywienia wiary, Ząbki 2012, s. 41.

Por. S. Dyk, Nowa ewangelizacja - konkretne wezwanie, s. 65.

Konferencja Episkopatów Ameryki Łacińskiej i Karaibów, Aparecida. VOgólna Konferencja Episkopatów Ameryki Łacińskiej i Karaibów. Dokument końcowy. Jesteśmy uczniami i misjonarzami Jezusa Chrystusa, aby nasze narody miaty w Nim życie, 548.

Por. EG 33.

Por. ibidem, 20. 
wspólnotą „wyruszającą w drogę”, która z radością i odwagą przyjmuje ewangelizacyjną inicjatywę ${ }^{89}$. Zostawiając swoim uczniom trudną i wymagającą misję głoszenia Ewangelii, Jezus pragnął, by Kościół nie był statyczny i pasywny, lecz dynamiczny i wychodzący naprzeciw człowiekowi. Musi w nim pojawić się nowa aktywność misyjna, która nie będzie udziałem jedynie wąskiej grupy specjalistów, ale zaangażuje każdego członka Ludu Bożego ${ }^{90}$. Potrzebny jest nowy rozmach w ewangelizacji, która będzie przeżywana jako codzienne zadanie poszczególnych chrześcijan i wspólnot. Misyjne przeobrażenie Kościoła postuluje zdynamizowanie i odnowienie działań ewangelizacyjnych.

\section{Pierwsze jest pierwsze - priorytetowa rola głoszenia kerygmatu i jego pierwszeństwo względem katechezy}

Według Franciszka ewangelizacyjne przeobrażenie Kościoła zakłada również nadanie priorytetowej roli pierwszemu przepowiadaniu, a więc kerygmatowi. Pierwsze głoszenie musi zająć pierwsze miejsce we wszelkiej działalności wspólnoty Kościoła ${ }^{91}$. Bez pierwszeństwa w głoszeniu kerygmatu nie może istnieć prawdziwa ewangelizacja ${ }^{92}$. Wychodząc do ludzi, którzy odeszli od Boga i zaniechali praktyk religijnych lub spełniają je jedynie w sposób zewnętrzny, pierwsze przepowiadanie stanowi uprzywilejowany sposób ewangelizacji ${ }^{93}$. Choć na jego rolę wskazuje już sama nazwa i wydaje się to być oczywiste, praktyka pokazuje, że niestety często bywa inaczej.

W kościelnym przepowiadaniu miejsce kerygmatu niejednokrotnie zajmuje katecheza. Papież Jan Paweł II nauczał, że pierwsze głoszenie i katecheza są dwoma różnymi rodzajami przepowiadania ${ }^{94}$. Stanowią one komplementarne i następujące po sobie kroki duszpasterskiego oddziaływania. Jose Prado Flores twierdzi, że „tworzą nierozłączny dwumian, w którym wszystko ma swoje miejsce i w którym granice

\footnotetext{
$89 \quad$ Por. EG 24.

90 Por. Lin 24.

91 Por. EG 164.

92 Por. ibidem, 110.
}

93 Por. Kongregacja ds. Duchowieństwa, Dyrektorium Ogólne o Katechizacji, Poznań 1998, 58; Jan Paweł II, Posynodalna adhortacja apostolska o Jezusie Chrystusie, który żyje w Kościele, jako źródło nadziei dla Europy Ecclesia in Europa (dalej: EE), Wrocław 2003, 46.

94 Por. Jan Paweł II, Posynodalna adhortacja apostolska o katechizacji Catechesi tradendae (dalej: CT), Kielce 1996, 19. 
Teologia papieża Franciszka połączone są wieloma mostami" ${ }^{\prime 95}$. Obie formy przepowiadania są niezbędne i żaden z nich nie może zastąpić drugiego, ale jednocześnie nie może mieć miejsca zamiana ich kolejności w procesie ewangelizacji, gdyż różnią się ze względu na treści i zamierzone cele. Kerygmat, mający w swym sercu bezwarunkową miłość Boga objawioną w Jego Synu, prowadzi do osobistego spotkania z Nim i doświadczenia Zbawienia, które staje się udziałem człowieka przez decyzje wiary, nawrócenia i poddania życia Jezusowi. Skierowany jest on przede wszystkim do serca człowieka. Katecheza natomiast stawia sobie za cel rozwój wiary i prowadzenie człowieka do pełnej komunii z Chrystusem ${ }^{96}$. Jej treścią jest całość nauczania Magisterium Kościoła, normy moralne, dogmaty i prawdy wiary, wywody apologetyczne i prawidła życia duchowego. Oddziałuje w sposób szczególny na wolę i rozum człowieka. W uproszczeniu można stwierdzić, że kerygmat rodzi człowieka do nowego życia, a katecheza ma za zadanie doprowadzić go do życia w obfitości ${ }^{97}$.

Franciszek wskazuje, że aby działalność Kościoła rzeczywiście rodziła żywą wiarę i prowadziła do Boga, przepowiadanie kerygmatyczne musi stać się absolutnym priorytetem ${ }^{98}$. W przeciwnym wypadku katecheza usiłuje w człowieku karmić życie, które w ogóle nie zostało w nim zrodzone ${ }^{99}$. Bardzo często ma miejsce sytuacja, w której w nauczaniu katechetycznym uczestniczą osoby potrzebujące pierwszego głoszenia ${ }^{100}$. Kiedy w Kościele zamieniamy kerygmat w katechezę, a żywe świadectwo wiary w nauczanie teologiczne, odbiorcy ewangelizacji nie spotkają żywego Boga. Zostanie im przekazana nauka i chrześcijańskie wartości, będą posiadali wiedzę o istocie Boga, prawdę o powszechności Zbawienia i mądre tezy z pneumatologii, ale nie doświadczą osobiście bycia ukochanymi dziećmi Ojca, zbawienia w Jezusie Chrystusie i nowego życia w Duchu Świętym ${ }^{101}$. Prawdy moralne i prawa wiary podane człowiekowi przed Jego spotkaniem z Bogiem, będzie on najczęściej odbierał jako niezrozumiałe krępowanie jego wolności, w związku z czym nie będzie chciał przyjąć ani tego nauczania, ani Kościoła, który nim go karmi. Zupełnie inaczej

$95 \quad$ Por. J. P. Flores, Nowi ewangelizatorzy dla nowej ewangelizacji, s. 62.

96 Por. Konferencja Episkopatu Polski, Dyrektorium katechetyczne Kościoła katolickiego w Polsce, Kraków 2001, 21-22.

Por. J. P. Flores, Jak ewangelizować ochrzczonych, Łódź 1993, s. 14-15. Por. EG 110.

Por. J. P. Flores, Jak ewangelizować ochrzczonych, s. 14.

Por. Lin 19.

J. P. Flores, Nowi ewangelizatorzy dla nowej ewangelizacji, s. 159. 
jest w przypadku, gdy zostanie zachowanie pierwszeństwo kerygmatu. Głęboko głoszone treści kerygmatyczne prowadzić będą człowieka do przyjęcia norm moralnych i prawd wiary, do których zacznie on dostosować swoje życie.

Priorytetowa rola kerygmatu w ewangelizacji domaga się przełożenia akcentu z duszpasterstwa skoncentrowanego na nauczaniu moralnym i sakramentalizacji na rzecz duszpasterstwa misyjnego, nastawionego na aktywne poszukiwanie osób nieznających Chrystusa osobiście ${ }^{102}$. Nie oznacza to w żadnym wypadku odejścia od pierwszego rodzaju duszpasterstwa, gdyż jest ono niezbędne dla rozwoju i dojrzewania w wierze. Nie może ono jednak zastąpić pierwszego głoszenia, gdyż prawdy moralne i teologia sakramentów nie służą rodzeniu człowieka do nowego życia w Chrystusie, lecz prowadzą do umocnienia i wzrostu tego życia. W minionych wiekach w Kościele sprawowanie sakramentów dominowało nad głoszeniem słowa, uznawano bowiem, że kraje chrześcijańskie są już wystarczająco zewangelizowane i nie potrzebują ewangelizacji. W rzeczywistości jednak warunkiem duszpasterstwa sakramentalnego i nauczania katechetycznego jest głoszenie kerygmatyczne ${ }^{103}$. Ewangelizacyjne przeobrażenie Kościoła wymaga, by oczyścić kerygmat z elementów katechetycznych i apologetycznych, które pojawiły się w nim w ostatnich stuleciach. Tylko wówczas będzie on mógł realizować swój podstawowy cel, a więc prowadzić do żywego spotkania z Chrystusem we wspólnocie Kościoła.

Fakt, iż kerygmat jest pierwszy, nie oznacza, że ma się pojawić jedynie na początku ewangelizacji, a później można o nim zapomnieć lub zastąpić go innymi treściami. Jest on pierwszy ze względów jakościowych, gdyż stanowi główne orędzie, po które trzeba wciąż sięgać i wykorzystywać je również w nauczaniu katechetycznym ${ }^{104}$. Papież Franciszek przypomina, że cała formacja katechetyczna wypływa z kerygmatu i jest jego pogłębieniem. Pierwsze głoszenie zawsze pozostaje rdzeniem katechezy, oświeca ją i pozwala w pełni zrozumieć poruszane w niej kwestie ${ }^{105}$. Głoszenie kerygmatyczne musi nieustannie powracać na usta ewangelizatora ${ }^{106}$. Nie może ono zostać zaniechane po spełnieniu swojej roli i doprowadzeniu człowieka do żywej relacji z Bogiem. Pierwszeństwo kerygmatu polega na niegasnącej

Por. S. Dyk, Nowa ewangelizacja - konkretne wezwanie, s. 150.

103 Por. K. Koch, Misja czy dymisja Kościoła, s. 45.

104 Por. EG 164.

105 Por. ibidem, 165.

106 Por. ibidem, 164.
} 
Teologia papieża Franciszka

aktualności i potrzebie ciągłego wsłuchiwania się w niego, także ludzi zaangażowanych w dzieło nowej ewangelizacji.

\section{Nowe wino wlewa się do nowych bukłaków - nowość metod i form ewangelizacji}

Postulat duszpasterskiego nawrócenia pociąga za sobą potrzebę zrewidowania dotychczasowych metod i form przekazu Ewangelii. Przekształcające się warunki społeczno-kulturowe sprawiły, że niektóre ze sposobów i środków ewangelizacji utraciły moc swego oddziaływania. Zmieniający się język komunikacji niektóre z nich pozostawił w tyle, czyniąc je niezrozumiałymi dla współczesnego człowieka ${ }^{107}$. Nowe okoliczności życia kwestionują utarte schematy i osłabiają działanie konwencjonalnych dróg głoszenia Dobrej Nowiny, co sprawia, że Kościól jest zobowiązany do odważnego spojrzenia na te środki i odpowiedzi na pytanie, czy używanie ich jest wciąż zasadne, czy też należy $\mathrm{z}$ nich zrezygnować ${ }^{108}$. Nie można zamknąć się w tradycyjnej kulturze kościelnej i metodach pracy, które utraciły dziś swą skuteczność ${ }^{109}$.

Nowe metody i środki wyrazu mają rodzić się wskutek pomysłowości nowych ewangelizatorów, którzy w ich odkrywaniu powinni wykorzystywać osiągnięcia psychologii, pedagogiki i socjologii ${ }^{110}$. Autor Evangelii gaudium przypomina, że wielkość i znaczenie treści nowej ewangelizacji nie może przesłaniać ogromnego znaczenia metod i środków, jakimi należy się posługiwać ${ }^{111}$. Lineamenta wskazują, że należy wypracować takie metody i formy przepowiadania, które przedstawią Boga w nowy sposób, zdolny odpowiedzieć na ludzkie pragnienia pokoju, prawdy i pełni życia ${ }^{112}$. Troska o nowe sposoby głoszenia Ewangelii nie jest działaniem jedynie technicznym, ale głęboko duchowym. Z jednej strony jest ona przejawem miłości względem Boga, która poświęca swe zdolności i talenty, aby jak najowocniej wypełnić powierzone przez Niego zadanie ${ }^{113}$. Z drugiej zaś strony

107

Por. EG 41.

Por. Cz. Parzyszek, Znaczenie nowej ewangelizacji dla odnowy wspótczesnego świata, s. 283.

Por. P.-A. Giffard, Wzrastanie Kościoła. Narzędzia i sposoby ożywienia wiary $w$ parafii, s. 20 .

Por. R. Kamiński, Działalność zbawcza Kościoła w teorii i praktyce pastoralnej, Lublin 2007, s. 129-133.

Por. EG 156.

Por. Lin 19.

Por. EG 156. 
poszukiwanie nowych metod i form przepowiadania stanowi przejaw miłości do drugiego człowieka, gdyż jest ono próbą ofiarowania mu czegoś, o jak największej wartości. Nowe mają być również miejsca papieża wykorzystywania metod i form ewangelizacji, gdyż tradycyjne ich miejsca są coraz rzadziej uczęszczane. Potrzeba miejsc pełnych życia i atrakcyjnych dla współczesnego człowieka, gdyż tylko one pozwolą ewangelizatorom się z nim spotkać i głosić mu słowo życia ${ }^{114}$.

Nowy język przepowiadania Dobrej Nowiny ma przekazywać ją człowiekowi w zrozumiały i odpowiedni dla niego sposób tak, by przenikała jego serce i prowadziła do spotkania z Bogiem. Nowi ewangelizatorzy nie używają języka, który jest zbyt ogólny, pozostaje poza rzeczywistością odbiorcy lub nie potrafi ukazać doniosłego znaczenia Ewangelii ${ }^{115}$. Dobra Nowina powinna być przepowiadana tak, by budziła w adresatach pragnienie Boga, zaspokajała je w pełni i udzielała odpowiedzi na obecne w ich sercach tęsknoty ${ }^{116}$. W procesie ewangelizacji za priorytet uznać należy rzeczywiste potrzeby i pytania osób ewangelizowanych, w przeciwnym bowiem wypadku Dobra Nowina stanie się pozbawioną wpływu na życie abstrakcją ${ }^{117}$. Nowy język nie ogranicza się do powtarzania utartych terminów chrystologicznych, ale usiłuje przedstawić Jezusa i Jego zbawcze dzieło w kontekście aktualnego pojmowania rzeczywistości i współczesnych doświadczeń egzystencjalnych ludzi. W doborze odpowiedniego języka głoszenia Ewangelii chodzi o jej powtórną interpretację w świetle dzisiejszych sposobów myślenia i rozumienia otaczającego nas świata ${ }^{118}$. Trzeba pamiętać, że czym innym jest istota prawd wiary, a czym innym sposób jej formułowania, w związku z tym Kościół musi ,starać się wyrażać niezmienne prawdy w języku pozwalającym dostrzec ich stałą nowość"119.

Poszukiwaniu nowych metod, form i języka powinien przyświecać jeden cel - uczynienie ich drogą do osobistego spotkania człowieka

114 Por. J.-L. Moens, Na czym polega nowa ewangelizacja?, [w:] P. Sowa, K. Kaproń (red.), Kerygmatyczny impuls w Kościele, Gubin 2012, s. 26-27.

Por. B. Matuszczyk, Retoryka Kościoła dziś - „siedem grzechów głównych” wspótczesnego kaznodziejstwa, [w:] E. Laskowska (red.), Skuteczność słowa $w$ dziataniach politycznych i spotecznych. Materiaty konferencyjne. Bydgoszcz, 3-5 kwietnia 1997 r., Bydgoszcz 1999, s. 131n.

Por. M. Figura, Nowa ewangelizacja jako centralne zadanie Kościoła, Kolekcja Communio, t. 8, Nowa ewangelizacja, Poznań 1993, s. 16. pastoralnej, Lublin 2007, s. 256. 
Teologia papieża Franciszka

z żywym Bogiem ${ }^{120}$. Papież Franciszek w Evangelii gaudium zaprasza do odważnej i twórczej refleksji nad metodami i formami ewangelizacji, gdyż jest ona niezbędna w doprowadzeniu do celu działalności misyjnej Kościoła ${ }^{121}$. W refleksji tej nie należy obawiać się form wykraczających poza nasze przyzwyczajenia i łamiących utarte schematy. Nie można bać się również popełniania błędów czy odnoszenia porażek, gdyż są one wpisane w próbę inkulturacji Ewangelii. Z tych potknięć trzeba wyciągać konkretne wnioski i przekuwać je na przyszły sukces ${ }^{122}$. W procesie tym nie wolno przede wszystkim zapomnieć, iż źródłem ewangelizacyjnej twórczości i pomysłowości jest Duch Święty, który nieustannie obdarza ewangelizatorów swoimi darami ${ }^{123}$.

\section{Nawrócenie struktur kościelnych}

Ewangelizacyjne i duszpasterskie nawrócenie ma dotknąć również struktur kościelnych. Ich reforma ma zmierzać w tym kierunku, by stały się one całkowicie nastawione na ewangelizację ${ }^{124}$. Dążenie do ewangelizacyjnego nawrócenia duszpasterstwa sprawia, że nie można zgadzać się na pozostawienie struktur kościelnych w takim stanie, w jakim się znajdują. Aktualne uwarunkowania społeczno-kulturowe doprowadziły do sytuacji, w której nie można się zadowolić zwykłym administrowaniem tym, co Kościół posiada, ale konieczne jest znalezienie się w „permanentnym stanie misji”125. Lineamenta do Synodu Biskupów nt. nowej ewangelizacji podkreślają, iż poważną przeszkodą w odnowie struktur kościelnych jest „zwykłe powielanie stereotypowych czynności"126. Jeśli nie są one podporządkowane realizacji zasadniczego powołania Kościoła, którym jest głoszenie Ewangelii, nie mają one mocy oddziaływania na współczesnego człowieka i nie rodzą w nim życia ${ }^{127}$. W celu odmiany struktur i nadania im mocy ewangelizacyjnego oddziaływania, należy z pełną pokory odwagą pójść naprzód zachowując to, co wciąż przynosi owoce, zostawiając za sobą to, co nie

\footnotetext{
120 Por. S. Dyk, Nowa ewangelizacja-konkretne wezwanie, s. 276.

121 Por. EG 33.

A. Shorter, Toward a theology of inculturation, New York 1988, s. 252.

Por. S. Dyk, Nowa ewangelizacja - konkretne wezwanie, s. 276.

Por. EG 27.

EG 25.

Lin 18.

Por. EG 26.
} 
rodzi życia, i szukając tego, co pozwoli zebrać jeszcze bardziej obfite żniwo w dziele ewangelizacji świata.

\section{Zakończenie}

Misyjne przeobrażenie Kościoła i nawrócenie duszpasterstwa jest jednym z podstawowych postulatów w nauczaniu papieża Franciszka. Widzi on w nim jedno z najważniejszych i najbardziej pilnych zadań, z którym musi się dziś zmierzyć wspólnota Kościoła. Misyjne przeobrażenie i nawrócenie Kościoła ma polegać przede wszystkim na jego całkowitym ukierunkowaniu na ewangelizację, które było doświadczeniem wspólnoty pierwszych chrześcijan. Wszystko w Kościele ma służyć jego pierwotnemu i podstawowemu powołaniu do głoszenia Ewangelii człowiekowi i wprowadzaniu go w doświadczenie osobistego spotkania z Bogiem. Gdy tak się nie dzieje, Kościół zaprzecza swojemu powołaniu, które stanowi o jego istocie, i nie realizuje w pełni najgłębszego pragnienia Boga, dotyczącego zbawienia wszystkich ludzi.

Refleksja w tej dziedzinie jest niezbędna zarówno na poziomie Kościoła powszechnego i jego struktur, jak również w poszczególnych diecezjach, których cała działalność pastoralna ma być kształtowana tak, by jak najowocniej głosić Ewangelię współczesnemu człowiekowi. Szczególną przestrzenią potrzebującą misyjnego przeobrażenia jest podstawowa komórka wspólnoty wierzących, czyli parafia. Zdaniem papieża Franciszka ma ona być całkowicie ukierunkowana na misję, a pozyskiwanie nowych członków poprzez realizację dzieła nowej ewangelizacji ma stać się jej absolutnym priorytetem. Nawrócenie duszpasterskie i zaangażowanie w dzieło nowej ewangelizacji ma stać się udziałem nie tylko osób duchownych i konsekrowanych, ale wszystkich członków Ciała Chrystusowego, którzy przez sakramenty chrztu i bierzmowania uczestniczą w prorockiej misji Chrystusa. Życie każdego z ochrzczonych ma nabierać ewangelizacyjnego ukierunkowania, które będzie się przejawiać w pełnym zapału i gorliwości podjęciu osobistego powołania do głoszenia Ewangelii. Autor Evangelii gaudium podkreśla, że chrześcijanie są zawsze uczniami-misjonarzami. Uczniami, gdyż podstawą wszelkiej działalności ewangelizacyjnej jest trwanie w osobowej relacji z Bogiem i kształtowanie życie według praw Ewangelii. Misjonarzami, gdyż wezwanie do nowej ewangelizacji stanowi podstawę ich chrześcijańskiego powołania, bez realizacji której nie mogą nazywać się uczniami i chrześcijanami.

Papież Franciszek wskazuje na wizję Kościoła wychodzącego ku człowiekowi, by go odnaleźć w jego środowisku życia, wprowadzić 
Teologia papieża Franciszka

w zażyłą relację z Chrystusem i włączyć we wspólnotę. Nie może się to dokonać, jeżeli ochrzczeni pozostaną w murach swoich kościołów w biernym oczekiwaniu, aż ludzie nieznający Boga odnajdą ich i poproszą o ewangelizację. Uczniów-misjonarzy ma cechować dynamizm wyjścia, nie tylko w rozumieniu dosłownym, ale również w znaczeniu wyjścia poza siebie - poza utarte schematy i wygodne kryterium duszpasterskie stwierdzające „zawsze się tak robiło” lub „nigdy się tak nie robiło”. Kościół ma być wspólnotą „wyruszającą w drogę”, która z radością podejmuje dzieło ewangelizacyjne. Wiąże się z tym konieczność sięgnięcia po nowe formy i metody głoszenia Ewangelii, dostosowane do zmieniających się warunków społeczno-kulturowych. Należy zrewidować dotychczasowe sposoby przekazu Dobrej Nowiny i z odwagą zrezygnować z tych, które utraciły moc oddziaływania. Nowa ewangelizacja wymaga nowego języka, zrozumiałego dla współczesnego człowieka i zdolnego doprowadzić go do osobistego spotkania z Bogiem. Według papieża Franciszka postulat misyjnego przeobrażenia Kościoła i nawrócenia duszpasterstwa domaga się uznania priorytetowej roli pierwszego głoszenia, czyli chrześcijańskiego kerygmatu o miłości Boga i zbawieniu w Jezusie Chrystusie. Kerygmat, który rodzi człowieka do nowego życia z Bogiem, zawsze winien poprzedzać nauczanie katechetyczne, która pozwala zrodzonemu życiu rozwinąć się i dojść do pełni. Głoszenie kerygmatyczne ma nieustannie powracać na usta ewangelizatorów i przenikać całe dzieło ewangelizacyjnej misji Kościoła.

Słowa kluczowe: nowa ewangelizacja, nawrócenie duszpasterstwa, nawrócenie pastoralne, Franciszek, Evangelii gaudium.

\section{Bibliografia:}

1. Augustin G. (red.), Nowa ewangelizacja. Impulsy do ożywienia wiary, Ząbki 2012.

2. Augustin G., Drogi skutecznej ewangelizacji, [w:] idem (red.), Nowa ewangelizacja. Impulsy do ożywienia wiary, Ząbki 2012.

3. Dias I., Ewangelizacja dzisiaj, [w:] G. Augustin (red.), Nowa ewangelizacja. Impulsy do ożywienia wiary, Ząbki 2012.

4. Dyk S., Nowa ewangelizacja - konkretne wezwanie, Gubin 2015.

5. Figura M., Nowa ewangelizacja jako centralne zadanie Kościoła, Kolekcja Communio, t. 8, Nowa ewangelizacja, Poznań 1993.

6. Flores J. P., Nowi ewangelizatorzy dla nowej ewangelizacji, Poznań 2013.

7. Franciszek, Adhortacja apostolska o głoszeniu Ewangelii w dzisiejszym świecie Evangelii gaudium, Kraków 2013. 
8. Giffard P.-A., Wzrastanie Kościoła. Narzędzia i sposoby ożywienia wiary $w$ parafii, Gubin 2013.

9. Jan Paweł II, Posynodalna adhortacja apostolska o Jezusie Chrystusie, Franciszka który żyje w Kościele, jako źródło nadziei dla Europy Ecclesia in Europa, Wrocław 2003.

10. Jan Paweł II, Posynodalna adhortacja apostolska o katechizacji Catechesi tradendae, Kielce 1996.

11. Kamiński R., Działalność zbawcza Kościoła $w$ teorii i praktyce pastoralnej, Lublin 2007.

12. Koch K., Misja czy dymisja Kościoła, [w:] G. Augustin (red.), Nowa ewangelizacja. Impulsy do ożywienia wiary, Ząbki 2012.

13. Konferencja Episkopatów Ameryki Łacińskiej i Karaibów, Aparecida. $V$ Ogólna Konferencja Episkopatów Ameryki Łacińskiej i Karaibów. Dokument końcowy. Jesteśmy uczniami i misjonarzami Jezusa Chrystusa, aby nasze narody miaty $w$ Nim życie, Gubin 2014.

14. Konferencja Episkopatu Polski, Dyrektorium katechetyczne Kościoła katolickiego w Polsce, Kraków 2001.

15. Kongregacja ds. Duchowieństwa, Dyrektorium Ogólne o Katechizacji, Poznań 1998.

16. Matuszczyk B., Retoryka Kościoła dziś - „siedem grzechów głównych” wspótczesnego kaznodziejstwa, [w:] E. Laskowska (red.), Skuteczność słowa $w$ działaniach politycznych i społecznych. Materiaty konferencyjne. Bydgoszcz, 3-5 kwietnia 1997 r., Bydgoszcz 1999.

17. Medina N., Dwanaście błędów, których nie możemy popetnić, [w:] P. Sowa, K. Kaproń (red.), Kerygmatyczny impuls w Kościele, Gubin 2012.

18. Moens J.-L., Na czym polega nowa ewangelizacja?, [w:] P. Sowa, K. Kaproń (red.), Kerygmatyczny impuls w Kościele, Gubin 2012.

19. Parzyszek Cz., Znaczenie nowej ewangelizacji dla odnowy wspótczesnego świata, Ząbki 2012.

20. Paweł VI, Adhortacja apostolska o ewangelizacji w świecie współczesnym Evangelii nuntiandi, Wrocław 2001.

21. Pignatiello L. M., Comunicare la fede. Saggi di teologia pastorale, Torino 1996.

22. Przyczyna W., Ewangelizacja, [w:] R. Kamiński (red.), Leksykon teologii pastoralnej, Lublin 2007.

23. Rada ds. Apostolstowa Świeckich przy Episkopacie USA, Co-workers in the vineyard of the Lord: A resource for guiding the development of lay ecclesial ministry, Washigton DC 2005.

24. Rey D., Definicja nowej ewangelizacji, [w:] P. Sowa, K. Kaproń (red.), Kerygmatyczny impuls w Kościele, Gubin 2012.

25. Ryś G., Nowa ewangelizacja dla przekazu wiary, [w:] G. W. Dryl (red.), Nowy człowiek $w$ dziele nowej ewangelizacji, Kraków 2013.

26. Shorter A., Toward a theology of inculturation, New York 1988.

27. Sobór Watykański II, Dekret o ekumenizmie Unitatis redintegratio, [w:] Sobór Watykański II. Konstytucje. Dekrety. Deklaracje, Poznań 2002. 
Teologia papieża Franciszka
28. Sobór Watykański II, Dekret o misyjnej działalności Kościoła Ad gentes divinitus, [w:] Sobór Watykański II. Konstytucje. Dekrety. Deklaracje, Poznań 2002.

29. Synod Biskupów - XIII Zwyczajne Zgromadzenie Ogólne, Nowa ewangelizacja dla przekazu wiary chrześcijańskiej. Lineamenta, Watykan 2011.

30. Wal J., Diakonia wspólnoty a przekaz wiary chrześcijańskiej, [w:] G. W. Dryl (red.), Nowy człowiek $w$ dziele nowej ewangelizacji, Kraków 2013.

31. White M., Corcoran T., Odbudowana. Czyli jak przebudzić wiernych, dotrzeć do zagubionych i nadać Kościołowi znaczenie, Gubin 2013. 